\title{
Eulalia picta Kinberg, 1866 - tube builder or specialized predator?
}

\author{
Krzysztof PABIS and Robert SOBCZYK \\ Department of Invertebrate Zoology and Hydrobiology, \\ Laboratory of Polar Biology and Oceanobiology, University of Łódź, \\ Banacha 12/16, 90-237 Łódź, Poland \\ * corresponding author <cataclysta@wp.pl>
}

\begin{abstract}
Twenty six specimens of the polychaete Eulalia picta were found in finegrained sand tubes. Material was collected in the Antarctic fjord, Admiralty Bay at the depth of about $100 \mathrm{~m}$. The comparison of tube sediment with the sediment composition at the collection site demonstrated that tubes were created with a high degree of particle selection. Our findings might suggest presence of the tube-building behavior in E. picta or show that this species is a highly specialized predator crawling into the tubes of other sessile polychaetes and uses their tubes as protective cases.
\end{abstract}

Key words: Antarctic, Admiralty Bay, tubes, sediments, Eteoninae, Phyllodocidae.

\section{Introduction}

Phyllodocidae are a group of marine polychaetes occurring worldwide, mostly at shelf depths. There are more than 500 species currently described (Pleijel 1991; Rouse and Pleijel 2001; Eklöf et al. 2007).

Data on the biology and ecology of Phyllodocidae are very scarce (e.g. Emson 1977; Fauchald and Jumars 1979; Lee et al. 2004 and references therein). According to current knowledge, it is assumed that all phyllodocids are active predators or scavengers (Rouse and Pleijel 2001; Jumars et al. 2015). Their buccal organ is an unarmed eversible pharynx. They actively search for prey, which includes other polychaetes, bivalves or gastropods (Fauchald and Jumars 1979; Rouse and Pleijel 2001). One species is probably hematophagous (Jenkins et al. 2002). None of the known phyllodocids is tubiculous. Many other polychaetes construct tubes from sediment particles or from protein secretion encrusted with calcium carbonate. In general the tubiculous species are sessile or discretely motile and most of them are filter or deposit feeders (Rouse and Pleijel 2001). There is still 
a considerable lack of research dedicated to the composition and mechanism of tube building in polychaetes (e.g. Gremare 1988; Willems et al. 2007; Noffke et al. 2009). Nevertheless, it was already demonstrated that the presence of the tube-building behavior may also reflect the character of the feeding mode and other elements of the biology and ecology (Brown and Ellis 1971).

Eulalia picta Kinberg, 1866 is a medium-size Antarctic phyllodocid that occurs on hard and soft bottom (Hartman 1964; Averincev 1972; Pabis and Siciński 2010). All morphological features place this species among other typical members of this family. Characters such as muscular pharynx and numerous well developed parapodia may suggest that this species is an active predator or scavenger. However, it was already demonstrated that such morphological adaptations are not necessarily, evidence of carnivorous behavior. A common European nereidid Hediste diversicolor (O.F. Müller 1776), a species with welldeveloped jaws and an eversible buccal organ, can feed exclusively as a filterfeeder (Rijsgård 1994). Discovery of the larger number of E. picta specimens hidden in fine-grained sediment tubes may lead to more than one possible explanation; either this polychaete is able to construct the tubes or it is a highly specialized predator crawling into the tubes of other polychaetes. The analysis of the grain size structure of the tubes was provided in relation to granulometry of adjacent sediments. The possible explanations of these findings are discussed.

\section{Material and methods}

Study area. - Admiralty Bay is an Antarctic fjord-like embayment of King George Island (South Shetlands). It consists of the central basin and three inlets (MacKellar Inlet, Martel inlet and Ezcurra Inlet) and covers an area of about $120 \mathrm{~km}^{2}$. A large part of the shoreline is covered with glaciers and the basin is influenced by a high rate of glacial disturbance. The amount of suspended matter in the waters of Admiralty Bay varies from about $15 \mathrm{mg} \mathrm{dm}^{-3}$ in the central basin to over $100 \mathrm{mg} \mathrm{dm}^{-3}$ in the glacial bays (Pęcherzewski 1980, Siciński et al. 2011). The bottom sediments are poorly sorted mud and sandy mud (Siciński 2004, Campos et al. 2013). The central basin is the deepest part of the bay (maximum depth about $530 \mathrm{~m}$ ) and is open to the Bransfield Strait (Siciński et al. 2011).

Sampling and data analysis. - Samples were collected in the summer season of 2007 in the outlet part of the Ezcurra Inlet, at depths of about $100 \mathrm{~m}$. Material was collected using a van Veen grab $\left(0.1 \mathrm{~m}^{2}\right)$. Four replicate samples were gathered at each of four stations. An additional van Veen grab was collected for granulometric analysis of the bottom sediments at each station. Samples were sieved through $0.5 \mathrm{~mm}$ mesh and fixed in a buffered $4 \%$ formalin solution. 
Ten specimens with complete, well preserved tubes were chosen for grain size analysis of their tubes. All measurements of tube grain size were done under a stereomicroscope Leica 205C.

\section{Results}

Amongst 57 collected specimens of Eulalia picta 10 were completely hidden in tubes. Sixteen others were covered with remains of the tubes. Another 31 specimens were completely outside of tubes. The tubes were constructed of fine sand $(169.5 \pm 2.4 \mu \mathrm{m}$ grain size) sediment agglutinated with mucus secretion. The secretion layer was thin and semitransparent. Each tube consisted of a single layer of densely packed black and semi-transparent sand grains that almost completely covered the body of the worm. No shell fragments or foraminiferan tests were included. A few larger grains were also attached but no more than 3 or 4 per tube. In the case of the specimens hidden in complete tubes, only a small fragment of the animal was extracted, leaving most of the polychaete inside. Width of the tube was the same along the entire length. Sediment grain size was also similar at a whole length of the tube (Fig. 1).

Sediment structure at four analyzed stations varied from very fine-grained silt $(39.2 \pm 39.2 \mu \mathrm{m})$ at station BIII to fine-grained sand at station BIV $(126.3 \pm 17.6 \mu \mathrm{m})$. Sediments at station BI can be described as very finegrained sand $(62.3 \pm 17.6 \mu \mathrm{m})$ while at station BII, very coarse-grained silt $(42.2 \pm 16.5 \mu \mathrm{m})$ (Fig. 2). Therefore, the difference between the substrate available at studied site and grains used for construction of tubes show high degree selectivity (only the fine sand particles were used for tube building).

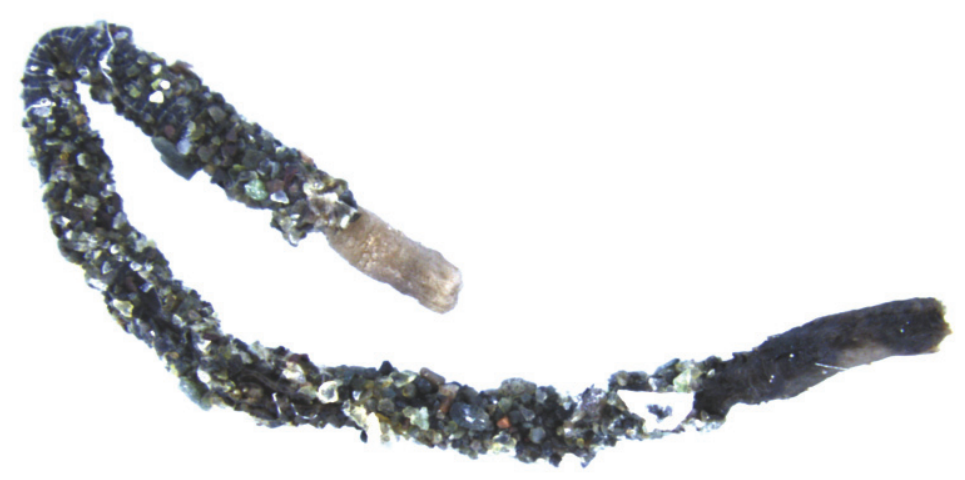

Fig. 1 Eulalia picta inside the tube. 


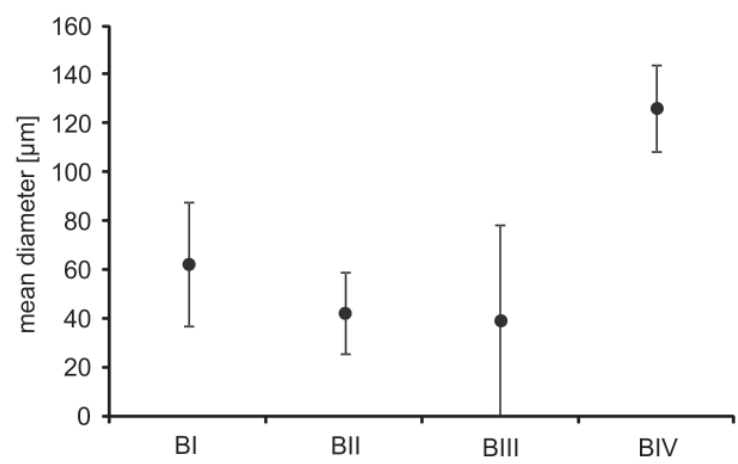

Fig. 2. Mean grain size with standard deviation at four sampling stations.

\section{Discussion}

Generally phyllodocids are considered active predators or scavengers, crawling on the bottom surface (Rouse and Plejel 2001; Jumars et al. 2015), however like most other polychaete families there are few detailed studies of their biology (e.g. Simon 1965; Olive 1975; Emson 1977; Fauchald and Jumars 1979; Jenkins et al. 2002; Lee et al. 2004). No phyllodocids are reported as tubiculous, although secretion of mucus is characteristic for many members of this family and some of them construct temporary protective cases of mucus that can loosely cover the body of the worm (Ushakov 1974). Eteone heteropoda Hartman, 1951 create mucous trails that are adhering sand grains (Simon 1965). Phyllodocids are also knows to crawl into the tubes of other polychaetes. In the material from the Admiralty Bay we observed specimens of Austrophyllum charcoti (Gravier 1911) inside the tubes of large sabellids (most probably Perkinsiana littoralis (Hartman 1967), although the number of such specimens was always very limited. Perkinsiana tubes are hard, solid structures and it is easy to crawl into them. Eulalia picta was found in thin and delicate mucous tubes. The body of the polychaete perfectly fit into the tube. If they were created by some other sessile tubiculous polychaetes it was probably not so easy to crawl inside them. Hartman-Schröder and Rosenfeldt (1988) already mentioned that E. picta can be found in mucus tubes encrusted loosely by sand grains. Nevertheless based on the current observations we cannot speculate about the origin of those tubes.

Our study showed that tubes are constructed of fine sand grains selected from the surrounding bottom sediments. It was demonstrated for some other polychaetes that their ability for selection of particles used for tube building can be quite high, and that they can select the particles smaller or larger than those that dominate in surrounding sediments (Dales 1957; Dufour et al. 2008; Noffke 
et al. 2009). However, it is worth mentioning that E. picta was absent from the near-glacial areas of the Admiralty Bay, where bottom sediments are highly dominated by silt and clay fractions (Siciński 2004; Campos et al. 2013). This fact is most probably related to the disturbance caused by a direct inflow of mineral suspension into the areas located in the vicinity of tidewater glaciers that may influence distribution of many animals in polar fjords (Włodarska-Kowalczuk and Pearson 2004; Siciński et al. 2011). Nevertheless, it can be also associated with sediment fractions preferred for tube building. Generally, the polychaete community in the outer region of the Ezcurra Inlet is characterized by a much higher number of tube building species (Pabis et al. 2015; Pabis and Sobczyk 2015). General morphology and structure of the E. picta tubes resembles the tubes of the common Antarctic maldanid Rhodine intermedia Arwidsson, 1911 and the owenid Galathowenia scotiae (Hartman 1966). Both of those species are also common and abundant in the Admiralty Bay. They dominated at sites that were sampled in our study but were much less abundant in the disturbed inner region of the fjord (Siciński 2004; Pabis and Sobczyk 2015). If that was the origin of the E. picta tubes it might prove that this species is highly specialized predator feeding on sessile maldanids or oweniids and uses their tubes as the refugium. The large number of specimens (altogether 26 individuals) that were hidden inside the tubes and earlier observations of Hartman-Schroder and Rosenfeldt (1988) shows that this is not an accidental situation. All tubes looked the same and match the description provided by Hartman-Schroder and Rosenfeldt (1988). The guts of E. picta were empty, suggesting carnivorous behaviour. We cannot fully exclude the possibility that E. picta is a first known tubiculous phyllocid polychaete, although the current knowledge suggests that this species is highly specialized predator and it is using tubes of other polychaetes which might create temporary protection against other predators.

Acknowlegdements. - Sampling campaign was supported by an International Polar Year related project (Structure, evolution, and dynamics of lithosphere, cryosphere and biosphere in European Sector of Arctic and in Antarctic No. PBZ-KBN-108/PO4/2004). This study was supported by University of Lodz internal funds. We want to thank James Blake and one anonymous reviewer for comments and critiques that helped to improve this article.

\section{References}

AVERINCEV V.G. 1972. Donnyje mnogoshchetinkovyje chervi Errantia Antarktiki i Subantarktiki po materialam Sovetskoj Antarkticheskoj Ekspedicii. [Benthic polychaetes Errantia from the Antarctic and Subantarctic collected by the Soviet Antarctic Expeditions.] Issledovanija Fauny Morej. 11 (19). Rezultaty Biologicheskich Issledovanij Sovetskich Antarkticheskich Ekspedicii 5: 88-293. 
BROWN P.L. and ElLIS D.V. 1971. Relation between tube-building and feeding in Neoamphitrite robusta (Polychaeta: Terebellidae). Journal of the Fisheries Research Board of Canada 28: $1433-1435$.

Campos L.S., Barboza C.A. M., Bassoi M., Bernardes M., Bromberg S., Corbisier T.N., FonTes R.F.C., GHEller P.F., HaJdu E., KaWAll H.G., LANGe P.K., LANNA A.M., LAVRAdo H.P., Monteiro G.C.S., Montone R.C., Morales T., Moura R.B., NaKayama C.R., Oackes T., Paranhos R., Passos F.D., Petti M.A.V., Pellizari V.H., Rezende C.E., RodRigues M., Rosa L.H., Secchi E., Tenenbaum D. and Yoneshigue-Valentin Y. 2013. Environmental processes, biodiversity and changes in Admiralty Bay, King George Island. Antarctica. Adaptation and Evolution in Marine Environment 2: 127-156.

DALES P. 1957. The feeding mechanism and structure of the gut of Owenia fusiformis Delle Chiaje. Journal of the Marine Biological Association of the United Kingdom 36: 81-89.

Dufour S.C., White C., Desrosiers G. and JunIPER K. 2008. Structure and composition of the consolidated mud tube of Maldane sarsi (Polychaeta: Maldanidae). Estuarine, Coastal and Shelf Science 78: 360-368.

EKLÖF J., PleiJel F. and SundBerg P. 2007. Phylogeny of benthic Phyllodicidae (Polychaeta) based on morphological and molecular data. Molecular Phylogenetic and Evolution 45: 261-71.

EMSON R.H. 1977. The feeding and consequent role of Eulalia viridis (O.F. Múller) (Polychaeta) in intertidal communities. Journal of the Marine Biological Association of the United Kingdom 57: 93-96.

FAUCHALD K. and JUMARS P.A. 1979. The diet of worms: a study of polychaete feeding guilds. Oceanography and Marine Biology: Annual Review 17: 193-284.

GALLAGHER E.D. 2008. Benthic feeding guilds and functional groups. Benthic Boundaries. Biological Oceanographic Processes: 1-27.

GRÉMARE A. 1988. Feeding, tube-building and particle-size selection in the terebellid polychaete Eupolymnia nebulosa. Marine Biology 97: 243-252.

HARTMAN O. 1964. Polychaeta Errantia of Antarctica. Antarctic Research Series 3: 1-131.

Hartman O. 1966. Polychaeta Myzostomidae and Sedentaria of Antarctica. Antarctic Research Series American Geophysical Union, Washington D.C.: 158 pp.

Hartmann-Schroeder G. and Rosenfeldt P. 1988. Die Polychaeten der Polarstern Reise ANT III/2 Teil 1: Euphrosinidae bis Chaetopteridae. Mitteilungen aus dem Hamburgischen Zoolgische Museum und Institut. 85: 25-72.

Jenkins C.D., WARD M.E., TURnIPSEED M., OSTERBERG J. and VAN DOVER C.L. 2002. The digestive system of the hydrothermal vent polychaete Galapagomystides aristata (Phyllodocidae): evidence for hematophagy? Invertebrate Biology 121: 243-254.

JuMARS P.A., DORGAN K.M. and LinDSAY S.M. 2015. Diet of worms emended: an update of Polychaete feeding guilds. Supplemental Material. Annual Review of Marine Science 7: 497-520.

LeE C.G., Huettel M., Hong J.S. and Reise K. 2004. Carrion-feeding on the sediment surface at nocturnal low tides by the polychaete Phyllodoce mucosa. Marine Biology 145: 575-583.

MANGUM C.P., SANTOS S.L. and RohodeS W.R.JR. 1968. Distribution and feeding in the onuphid polychaete, Diopatra cuprea (Bosc). Marine Biology 2: 33-40.

NoffKe A., Hertweck G., Kröncke I. and Wehrmann A. 2009. Particle size selection and tube structure of the polychaete Owenia fusiformis. Estuarine, Coastal and Shelf Science 81: $160-168$.

OLIVE P.J.W. 1975. Reproductive biology of Eulalia viridis (Múller) (Polychaeta: Phyllodocidae) in the north eastern U.K. Journal of the Marine Biological Association of the United Kingdom 55: 313-326. 
PABIS K., KĘDRA M. and GROMISZ S. 2015. Distinct or similar? Soft bottom polychaete diversity in Arctic and Antarctic glacial fjords. Hydrobiologia 742: 279-294.

PABIS K. and SiCIŃSKI J. 2010. Polychaete fauna associated with holdfasts of the large brown alga Himantothallus grandifolius in Admiralty Bay, King George Island, Antarctic. Polar Biology 33: 1277-1288.

PABIS K. and SOBCZYK R. 2015. Small scale spatial variation of soft bottom polychaete biomass in an Antarctic glacial fjord (Ezcurra Inlet, South Shetlands): comparison of sites at different levels of disturbance. Helgoland Marine Research 69: 113-121.

PĘCHERZEWSKI K. 1980. Distribution and quantity of suspended matter in Admiralty Bay (King George Island, South Shetland Island). Polish Polar Research 1: 75-82.

PLEIJEL F. 1991. Phylogeny and classification of the Phyllodocidae (Polychaeta). Zoologica Scripta 20: 225-261.

RIJSGÅRD H.U. 1994. Filter-feeding in the polychaete Nereis diversicolor: a review. Netherlands Journal of Aquatic Ecology 28: 453-458.

Rouse G.W. and PleiJel F. 2001. Polychaetes. Oxford University Press, Oxford: 354 pp.

SICIŃSKI J. 2004. Polychaetes of Antarctic sublittoral in the proglacial zone (King George Island, South Shetland Islands). Polish Polar Research 25: 67-96.

Siciński J., Jażdżewski K., De Broyer C., Presler P., Ligowski R., Nonato E.F., CorbiSIER T.N., PETti M.A.V., Brito T.A.S., LAVRado H.P., BŁAŻEWICZ-PASZKOWYCZ M., PABIS K., JAŻDŻEWSKA A. and CAMPOS L.S. 2011. Admiralty Bay Benthos diversity - A census of a complex polar ecosystem. Deep-Sea Research II 58: 30-48.

SIMON J.L. 1965. Feeding in the annelid Eteone heteropoda. Quarterly Journal of the Florida Academy of Sciences 28: 370-372.

UshaKov P.V. 1974. Polychaetes of the suborder Phyllodociformia of the polar basin and the northwestern part of the Pacific (Families Phyllodocidae, Alciopidae, Tomopteridae, Typhloscolecidae, and Lacydoniidae). Izdatel'stvo "Nauka" Leningradskoe Otdelenie. Leningrad: $1616-1625$.

Willems W., Goethals P., Van den Eynde D., Van Hoey G., Van Lancker V., Verfaillie E., VINCX M. and DEGRAER S. 2007. Where is the worm? Predictive modeling of the habitat preferences of the tube-building polychaete Lanice conchilega. Ecological Modeling 4977: 1-6.

WŁodARSKA-KowalcZUK M. and PEARSON T.H. 2004. Soft-bottom mecrobenthic faunal associations and factors affecting species distributions in an Arctic glacial fjord (Kongsfjord, Spitsbergen). Polar Biology 25: 155-167. 